\title{
Increasing the policy impact and influence of the Ontario east economic development commission
}

\author{
Eric McSweeney, Ec.D.
}

The Ontario East Economic Development Commission (OEEDC) has provided an important vehicle to facilitate cooperation and partnership between municipalities and their economic development offices in Eastern Ontario. Among its many functions is to act as an advocate for Eastern Ontario on important economic development issues. This paper analyses the ability of OEEDC to impact and influence economic development policy and programs by conducting a survey to national, provincial and regional economic development associations on their experience engaging in policy influence. The author concludes that OEEDC has the possibility of having a larger and more active mandate for the organization.

Keywords: Ontario East Economic Development Commission (OEEDC), economic development policy

\section{Background: Ontario east economic development commission}

'Necessity is the mother of invention' is an old expression that sometimes applies in economic development. This was the case back in 1987, when Brockville could not support the cost of participating in the 'Opportunities Canada Show', so Doug Ellis of Brockville convinced eleven other Eastern Ontario municipalities to cooperatively participate and share expenses to exhibit at the show. This led to a meeting early the following year to discuss the formation of a cooperative marketing group, and the Ontario East Economic Development Commission (OEEDC) was born.

From the original fourteen members in 1988, the OEEDC has grown to about 100 members and represents the geographic area from Victoria-Haliburton Counties on the west to the United Counties of Prescott-Russell on the east and bounded by the Ottawa and St. Lawrence Rivers. Members include economic development officers, chief administrative officers, planners, municipal economic development committee members, community futures development corporations, utilities, real estate professionals, provincial representatives and related private sector businesses. The OEEDC currently operates with very limited resources; a 2003 operating budget of $\$ 51,410$ and one part-time staff person.

Cooperative marketing, the primary reason for its initiation, remains the focus and most vital function of the OEEDC. The overall goal of the OEEDC marketing program is to raise the 
profile of Eastern Ontario as a viable business location. Through the organization's co-operative marketing efforts, members obtain increased exposure for their own communities at very reasonable costs.

Members have participated under the 'Ontario East' marketing banner in more than 40 tradeshows and missions throughout Canada and the United States. The Commission has developed a series of professional marketing brochures, has placed advertisements in national and international business publications and has gone through three generations of branding images/logos. The OEEDC uses a professional team approach for successful programs such as 'Influencing the Influencer', which targets investment intermediaries such as real estate professionals and site location consultants.

Another function that the OEEDC serves is the support of education, professional development and information sharing for its members. For example, it organizes the largest annual municipal conference in Eastern Ontario which traditionally is held in Kingston. The fall conference is well attended by over 400 politicians and staff from both the Provincial and Municipal government levels as well as economic development professionals. In addition to four quarterly membership meetings of the Commission, separate professional development workshops are held throughout the year, often in cooperation with Provincial Ministries. For example, in December 2002, OEEDC co-sponsored with the Ontario Ministry of Food and Agriculture, a one-day workshop entitled 'The Theory and Real World Practice of Economic Impact Analysis' with Dr. Harry Kitchen of Trent University.

Finally, from time to time, the Commission acts as an advocate for Eastern Ontario on important economic development issues. It is this third and final activity area that is the subject of this paper.

\section{OEECD past and current advocacy role}

Since its inception, the Commission has impacted and influenced federal, provincial and local government, to varying degrees. The OEEDC has certainly been most directly involved with the Provincial government and its Ministries, however, it has had minimal involvement with the Federal Government. In the earlier years, the Commission proactively made its position known to Provincial parties through meetings and the presentation of briefs on a variety of issues. In more recent years, the OEEDC has moved more into a responsive role, with the Province seeking input from the Ontario East Economic Development Commission. 
Following is a record of 'advocacy' type briefs and meetings of the OEEDC.

\begin{tabular}{|l|l|}
\hline 1988-August & Honourable Sean Conway - Meeting \& Brief \\
\hline 1988-October & $\begin{array}{l}\text { Honourable Monty Kwinter and Honourable Sean Conway - Meeting } \\
\text { \& Brief }\end{array}$ \\
\hline 1989-April & Honourable Paul Dick - Meeting \& Brief \\
\hline 1989-August & Deputy Minister - Meeting \& Brief \\
\hline 1989-November & Liberal Caucus - Meeting \& Brief \\
\hline 1992-February & Honourable Len Hopkins - Chair,Liberal Caucus, Meeting \& Brief \\
\hline 1992-August & Honourable Ed Philips - Meeting \& Brief \\
\hline 1992-December & NDP Cabinet Committee - Brief \\
\hline 1994-November & Conservative Caucus - Meeting \& Brief \\
\hline 1995-February & Liberal Caucus - Meeting \& Brief \\
\hline 1995-March & Honourable Peter Adams, Chair, Government Caucus \\
\hline 1995-December & Honourable William Saunderson Meeting \& Brief \\
\hline 1996-March & Premier Mike Harris-Meeting \& Brief \\
\hline 2000-March & Premiers Task Force, Rural Economic Renewal Meeting \& Brief \\
\hline 2001 & $\begin{array}{l}\text { Minister Runciman's policy advisors, senior MEDT bureaucrats - } \\
\text { Meeting }\end{array}$ \\
\hline 2001-December & Smart Growth Management Councils - Brief \\
\hline 2002-November & Eastern Ontario Smart Growth Panel/MMAH Presentation \\
\hline 2002 - November & Michael Fenn, Deputy Minister, MMAH Meeting \\
\hline
\end{tabular}

Notable is the gap between 1996 and 2000, when no advocacy meetings or briefs were undertaken. Also noteworthy is the fact that all meetings and briefs up to and including 1996, were directed to elected representatives of senior governments. Three of the five meetings/briefs since that time were directed at Provincially-appointed bodies. The meeting with Deputy Minister Fenn was in connection with the presentation to the Smart Growth Panel. As already noted, the OEEDC has therefore become less proactive, particularly with Provincial politicians and becoming more reactive, responding to requests for input which are made by the Province. Provincial Ministers and MPPs do frequently participate at general meetings, and also participate in the Ontario East Municipal Conference.

With respect to impact on local economic development, the OEEDC influence has been mainly by means of marketing collaborations of its members. Through these marketing efforts, it soon becomes evident to those participating that collaboration in regional economic development efforts is really the only realistic way for smaller communities to have any chance of being noticed in a global economy. 
The need for regional collaboration and partnership is reinforced by the following quotation from the Report of the Premier's Task Force on Rural Economic Renewal:

"Due to lack of resources, experience and expertise, rural communities often struggle with what action to take in order to revitalize their local economies. In many instances, these communities see each other as the competition as opposed to being partners in regional economic development. An area-wide approach to strategic planning, tourism, marketing and project development would allow communities to build on their strengths and work together to develop a stronger rural economy. The reality of today's global economy makes the case for regional economic development strategies a compelling one."

The OEEDC has provided an important vehicle to facilitate cooperation and partnership between municipalities and their economic development offices in Eastern Ontario. Regular and ongoing communication between and among its members engenders a greater spirit of cooperation and to a certain extent, a shared sense of vision and destiny.

\section{Policy impact and influence of similar organizations}

\section{Survey of economic development associations}

An email survey of national, provincial and regional economic development associations was undertaken to develop an understanding of whether or not the economic development associations engage in policy influence, and if so, how they proceed to influence policy, and what methods they feel are most effective. The survey was supplemented with telephone interviews and additional emails as required. Following is a copy of the survey that was sent to the Economic Developers Council of Ontario (EDCO). The wording of each was customized or personalized to suit the target recipient. The questions asked were identical in all cases.

I am undertaking research on the ability of the Ontario East Economic Development Commission (OEEDC) ( $\langle$ http://www.onteast.on.ca/ $>$ ) to impact and influence economic development policy and programs, in fulfillment of the University of Waterloo's Year 3 academic requirements and to assist the OEEDC.

As EDCO is an important economic development organization, you are kindly invited to spend a few minutes contributing to this research. Your assistance would be greatly appreciated by "replying" to this email, indicating your responses to the questions below in the reply email. 
1. Does your organization attempt to influence or impact local, provincial or federal economic development policies or programs?

2. If so, how does it do this?

3. In your experience, what are the most effective means of influencing or impacting policies/programs at each of the three levels of government?

4. Would you like to receive a copy of this research paper?

Thank you for your cooperation and assistance.

\section{Economic developers association of Canada}

The Economic Developers Association of Canada (EDAC) attempts to influence policies at the federal level, depending upon the issue. EDAC tends to leave the provincial issues to the provincial associations, and only responds to provincial issues if requested to. EDAC's Board of Directors consist of three positions that are chosen by the membership at large; a representative from each province that has a provincial association; a corporate sponsor representative, and a federal government representative (from Investment Partnerships Canada). EDAC also has a working relationship and history with the Department of Foreign Affairs, Investment, and Trade as well as Industry Canada. EDAC does not receive any funding from the Federal Government for any of its operating costs, special programs, or educations seminars.

EDAC's most effective interventions usually involve contacting the federal department involved and/or the Ministers directly so that EDAC can be heard either in person, or through correspondence. Provincial counterparts are kept informed of positions taken. Two examples of intervention include PEMD-I funding and its subsequent extension, and comments on the Infrastructure Strategy.

\section{Economic development association of British Columbia}

The Economic Development Association of British Columbia (EDABC) is currently debating whether or not the influencing of government policy should be a core activity of their association. The question as viewed by EDABC is 'how do EDOs lobby politically, when EDOs answer to political masters and rely on government for much of our funding?' Although the Association has taken a consistent position of quiet lobbying for a variety of reasons, it has not often taken an aggressive stance on issues or programs, even though some members feel strongly that it should. 
At the local level, some EDOs 'lobby' (carefully) on a regular basis, either directly, with or through local politicians. EDOs do this in a variety of ways while employing both formal and informal channels.

\section{Economic development association of Alberta}

The Economic Developers Association of Alberta (EDAA) feels that it has effectively influenced provincial economic development policy. It has had Provincial staff on its Board for some time. Officially, there is one senior Provincial economic development official with voting privileges, although several others participate on a regular basis. There is a close working relationship between the Board and Provincial staff, which is seen to be of great benefit in keeping provincial policy in tune with needs identified by municipal economic development staff. Provincial staff members actively seek out the Association's opinion on economic development issues that arise, and in some cases, provincial politicians have actually promoted the Association and its education programs within their jurisdictions. The EDAA feels its greatest impact on local government is through its successful economic development education programs. The Association determined influence on policy to be one of its primary areas of activity some time ago and fully recommends that provincial staff be represented and participate at Board meetings.

\section{Saskatchewan economic developers association}

The Saskatchewan Economic Developers Association (SEDA) is a small non-profit organization with a half-time staff person. SEDA actively avoids direct advocacy and lobbying efforts, and instead focuses on the building of an economic development profession, and the professional development of practitioners (whether volunteer or paid) in Saskatchewan.

\section{Economic developers council of Ontario}

While a response was not received from the Economic Developers Council of Ontario (EDCO), it does have a policy committee.

\section{L'association des professionnels en développment économique du Québec}

For L'Association des Professionnels en Développement Économique du Québec (APDEQ), attempting to influence or impact local, provincial or federal economic development policies or programs is not currently a priority but the organization would like to be more active in this area. APDEQ utilizes its partnerships and relations with different government agencies to communicate its views on different topics. APDEQ usually meets with the Quebec Minister of Industry twice a year. There is a representative of the Quebec ministry on the board, and in the past there was also a federal ministry representative (Development Économique Canada). 
APDEQ has received sponsorship funding for specific events like its annual conference or its Spring meeting, in particular from Development Économique et Regionale (Quebec).

Nunavut economic developers association

The Nunavut Economic Developers Association (NEDA) encourages the Departments responsible for Economic Development in Nunavut, both Territorial and Federal, to invite NEDA members to participate in forums, discussion groups and consultations. NEDA invites Department heads and senior staff to attend the NEDA AGM and conferences, both to present their ideas and to listen to NEDA member concerns. The Economic Development 'officers' are all at the community level (local or municipal government), so EDOs also have the option of working through the municipal councils, Members of the Legislative Assembly, and/or MPs to bring concerns to their respective governments. Nunavut has a relatively small population base of 26,000 and, therefore, EDOs often personally know all of the government economic development officials. The old 'who you know syndrome' helps, but it doesn't necessarily work.

As Nunavut is only just beginning its fourth year, many forms of communication to influence economic development policy are being used, but in the opinion of the respondent, ongoing interaction and communication through meetings is likely to be the most productive.

\section{Greater Halifax partnership}

The Greater Halifax Partnership (GHP) was founded as a public-private partnership to manage growth of the Halifax Regional Municipality, which itself was formed in 1996 through the amalgamation of four local municipalities. At the provincial level, GHP delivers caucus and ministerial briefings, bringing the private sector perspective to strategy development and the economic planning process. Over the past few years targeted presentations have been made on specific strategy development processes in the energy sector, and on the economy as a whole. At the federal level GHP delivers briefings to MPs, ministers, deputy ministers and senior executives as appropriate. At the municipal level, the GHP conducts advisory group meetings that include the Mayor, Chief Administrative Officer (CAO), Municipal Councillors and representatives from the business community. The informal meetings allow these interests to discuss issues of real importance to the municipality and the business community in a way that is informative and real.

Representatives from all three levels of government sit on the board of directors including: the mayor and CAO of Halifax Regional Municipality, the Nova Scotia Vice-President of the Atlantic Canada Opportunities Agency, and the CEO of the Office of Economic Development for Nova Scotia. 
GHP is of the opinion that bringing the private and public sector together in a true partnership is the best way to influence strategy and policy making at all three levels of government. By allowing business leaders and government leaders to interact they are able to learn more about the priorities, needs, and opportunities of each other. It is through partnership and understanding that true change can be affected.

\section{Entreprise chaleur, New Bruswick}

Entreprise Chaleur is a community economic development agency representing the economic development interests of six municipalities in the Bathurst area. It does not formally attempt to influence economic development policy. However, Entreprise Chaleur maintains a close relationships with local and provincial partners to ensure that they understand the needs of the region; that they have the appropriate knowledge; and that they build flexibility into their programs to respond to the needs of local entrepreneurs.

At the provincial level, Entreprise Chaleur occasionally organizes fact-finding missions to the region for provincial staff so they can gain a better understanding of the area. This has improved and increased communication on both sides and has lead to a few initiatives beneficial for both parties. In addition, whenever the situation allows it, Entreprise Chaleur meets with the provincial and federal ministers from the region to outline the regional economic development policy and program needs. At the municipal level, Entreprise Chaleur keeps communications open between the mayors and Entreprise Chaleur by meeting with the mayors at least three times per year. From time to time, Entreprise Chaleur also meets with municipal managers to explain the needs of entrepreneurs.

Entreprise Chaleur is of the opinion that the best way to have an impact and influence on policy is to make civil servants aware of the economic development work environment, giving them a true picture of the region, and to aim for realistic objectives. Entreprise Chaleur would advise being patient but persistent if the organization truly believes in what they are trying to achieve. The board of Enterprise Chaleur consists only of business people, representing different economic sectors of importance to the region. Provincial and federal staff do attend the regular monthly meetings (but not executive meetings).

Enterprise Chaleur's annual budget of almost $\$ 400,000$ is funded by the Atlantic Canada Opportunities Agency (ACOA) (45 per cent), Business New Brunswick (20 per cent), Department of Training, Employment \& Development (20 per cent) and the six municipalities within the region (15 per cent). From time to time, ACOA and the province's Department of Training, Employment and Development provide additional funding for education seminars. The six municipalities do not have municipal economic development offices, and Enterprise Chaleur provides economic development services on their behalf. 


\section{Enterprise greater Moncton}

The Greater Moncton Economic Commission is a partnership of private and public sectors to coordinate regional development activities in the areas of service-to-business, investment attraction, marketing, sector development and advocacy. Enterprise Greater Moncton does influence economic development policy at all three levels of government, and all three levels are represented on the Board. Influence is achieved through having government representation on the Board; presentations to government on current issues; and leveraging the influence of its private sector partnership. It is funded by the private sector as well as the three levels of government.

\section{Northwestern Ontario development network}

In a rejuvenation effort in 1998, Northwestern Ontario Development Network (NODN) identified its members' community development needs as follows:

- Need for an instrument for advocacy and policy development at a regional level;

- Need for information and communication;

- Need for training and education.

The NODN has adopted the following vision statement. "The Northwestern Ontario Development Network is a unique, nonprofit, membership-driven organization that acts as a catalyst, contributing to a dynamic, sustainable economy in Northwestern Ontario through joint community cooperation, contact with other groups and opportunity identification". ${ }^{1}$

The NODN then adopted as part of its mission statement, the role of being a champion of regional community development issues. "The Network will participate as a leader on selected regional issues as identified by our members", and being "a champion for advocacy and policy development". Some of the NODN key activities in support of this goal include:

- Exploring and promoting infrastructure opportunities and needed improvements: e.g. energy, telecommunication, transportation, value-added opportunities;

- Initiating and coordinating responses to development issues and challenges, then representing membership concerns and options for improvement to senior levels of government on regional issues;

- Representing its membership to: Northwestern Ontario Municipal Association (NOMA); Northwestern Ontario Association of Chambers of Commerce (NOACC); Economic Developers Council of Ontario (EDCO); Ontario Association of Community Futures Development Corporations (OACFDC). ${ }^{2}$

\footnotetext{
${ }^{1}$ Source: Northwestern Ontario Development Network website: www.nodn.com

${ }^{2}$ Ibid
} 
NODN's order of priorities since 1998, have been policy development and advocacy, followed by marketing and investment attraction. NODN influences economic development policies or programs, primarily at the federal and provincial levels, especially in the area of export projects. The manner in which it does this however, is very different than other provincial or regional economic development associations. The NODN does not exert direct influence on economic development related policies. Instead, it has developed a memorandum of understanding with its partner organizations, in particular NOMA and NOACC, to represent views of common interest to the appropriate government agency or Minister.

NODN has always had both provincial and federal ministry representatives on the Board. Recently, the presidents of both NOMA and NOACC have joined the Board as ex-officio members. The NODN annual budget is approximately $\$ 150,000$ plus special project funding of more than $\$ 50,000$. A little over 10 per cent of the budget is derived from municipal membership fees of \$750/annum, and the balance of the budget is funded by FedNor (Industry Canada) and Ontario's Ministry of Northern Development and Mines, through 'fee for service' arrangements.

The following table summarizes the key features of the economic development organizations surveyed in Canada. The second column indicates whether or not the organization has federal and/or provincial staff participating on its board. The third column indicates whether or not it is within the mandate of the organization to attempt to influence government economic development policy through direct contact with politicians and bureaucrats. The 'o' symbol indicates that while the organization does not proceed to influence policy directly, informally this does occur. The last column indicates that the organization attempts to influence policy indirectly through the efforts of other organizations.

\begin{tabular}{|l|l|l|l|}
\hline Organization & $\begin{array}{l}\text { Fed/Prov Staff on } \\
\text { Board }\end{array}$ & $\begin{array}{l}\text { Influence } \\
\text { Directly }\end{array}$ & $\begin{array}{l}\text { Influence } \\
\text { Indirectly }\end{array}$ \\
\hline EDAC & Yes & $\sqrt{ }$ & \\
\hline EDABC & No & $\circ$ & \\
\hline EDAA & Yes & $\sqrt{ }$ & \\
\hline SEDA & Yes & No & \\
\hline EDCO & Yes & $\sqrt{ }$ & \\
\hline APDEQ & Yes & $\sqrt{ }$ & \\
\hline NEDA & No & $\sqrt{ }$ & \\
\hline GHP & Yes & $\sqrt{ }$ & \\
\hline Ent. Chaleur & No & $\circ$ & $\sqrt{ }$ \\
\hline
\end{tabular}




\begin{tabular}{|l|l|l|l|}
\hline EGM & Yes & $\sqrt{ }$ & \\
\hline NODN & Yes & & $\sqrt{ }$ \\
\hline
\end{tabular}

\section{Influence effectiveness of OEEDC survey}

To gauge the effectiveness of the OEEDC to impact and influence economic development policy for the benefit of Eastern Ontario, an email survey was conducted as part of the research for this assignment. The survey was sent to the following stakeholders in Eastern Ontario:

- OEEDC members, mainly economic development officers;

- County Wardens, Mayors, and Chief Administrative Officers (CAO) of the thirteen counties of Eastern Ontario;

- Members of Provincial Parliament for Eastern Ontario;

- Staff of the following Ministries: Municipal Affairs and Housing; Enterprise, Opportunity and Innovation; Agriculture and Food;

- Community Futures Development Corporations in Eastern Ontario (CFDC);

- Selected Chambers of Commerce, self-helf/entrepreneurship centres, and Business Improvement Areas (BIA);

- Eastern Ontario Smart Growth Panel.

Following is a copy of the survey that was used for most of the above groups. The introductory paragraph was customized or personalized to suit the target recipient(s). The questions asked were identical in all cases.

Good morning/afternoon:

As a person with a keen interest in economic development, you are kindly invited to contribute your opinion on the ability of the Ontario East Economic Development Commission (OEEDC) ( $<$ http://www.onteast.on.ca/ $>$ ) to impact and influence economic development policy and programs. The research is being undertaken in fulfillment of University academic requirements, and to assist the OEEDC. Your assistances would be greatly appreciated by "replying" to this email, indicating your responses to the questions below in the reply email. Strict confidentiality will be maintained in this analysis, and no information presented will be identifiable or attributable to any one respondent.

1) How would you rate the effectiveness of the Commission to impact or influence economic development related policies and programs in Eastern Ontario?

a) Extremely effective 
b) Somewhat effective

c) Effective

d) Somewhat ineffective

e) Ineffective, or

f) Don't know

2) What are your suggestions to increase the effectiveness of the Commission's influence on economic development related policies and programs?

3) Would you like to receive a copy of the results of this research?

Thank you in anticipation for your cooperation and assistance.

\section{OEEDC membership survey results}

In answer to the question, "How would you rate the effectiveness of the Commission to impact or influence economic development related policies and programs in Eastern Ontario", the following results were obtained from a 44 per cent response rate (21/48).

$\begin{array}{lr}\text { Extremely effective } & 17.5 \% \\ \text { Effective } & 27.5 \% \\ \text { Somewhat effective } & 10 \% \\ \text { Somewhat ineffective } & 20 \% \\ \text { Ineffective } & 15 \% \\ \text { Don't know } & 10 \%\end{array}$

One respondent indicated that it depended upon the issue - that the organization is extremely effective in some cases, not in others, and has also been everywhere in between during the respondent's time as a member. This response has not been included in the above chart.

In answer to the question, "What are your suggestions to increase the effectiveness of the Commission's influence on economic development related policies and programs", the following observations were offered by respondents.

- There were a few responses that questioned whether this is, or even should be a primary mandate of the OEEDC.

- Respondents generally rated the OEEDC as being more effective in impacting/influencing the local level than the Provincial level. The Federal level was felt to be the area of least impact/influence.

- At the local level, impact and influence was greatest in rural areas, and ineffective or had no influence in the large urban areas. 
- Impact at the local level results from the influence OEEDC has on the thinking of its own members, who in turn influence their own organizations and communities.

- Some members did not feel confident or knowledgeable enough (or were relatively new to the OEEDC) to rate the effectiveness or make suggestions.

- In terms of how to strengthen OEEDC's influence on policy development, the most common response was to get better known by and get in front of politicians and senior bureaucrats/decision makers (25 per cent of respondents). Positions taken should be supported by EDOs.

- It was also the view that:

- a mandate for influencing government be sought from membership;

o the issues of importance be derived from the membership;

- a policy committee be established;

○ there be focus by having a substantiated plan/ mandate/documented position papers professionally prepared on a limited number of issues to be pursued;

$\circ$ the expectations of government be clearly stated, and;

$\bigcirc$ the OEEDC policy positions (supported by the above) be put on the political agenda.

- Several respondents felt that a greater influence role (and a stronger image and greater media profile) would require greater staffing and financial resources.

- Upcoming federal, provincial and local elections were seen as an opportunity. New senior governments are often seeking input. The OEEDC is in a strategic position to provide this input. It was also suggested that OEEDC should approach each Council to seek their input and influence their direction, as well as, discuss the benefits of membership.

\section{Provincial staff survey results}

In answer to the question, "How would you rate the effectiveness of the Commission to impact or influence economic development related policies and programs in Eastern Ontario”, the following results were obtained from a 40 per cent response rate (4/10).

$\begin{array}{lc}\text { Extremely effective } & 25 \% \\ \text { Effective } & 25 \% \\ \text { Somewhat effective } & 50 \% \\ \text { Somewhat ineffective } & - \\ \text { Ineffective } & - \\ \text { Don't know } & -\end{array}$

In answer to the question: "What are your suggestions to increase the effectiveness of the Commission's influence on economic development related policies and programs", the following observations were obtained from those responding. 
- OEEDC is viewed by the Province as a lead organization when there is a need to consult on economic development issues;

- OEEDC is viewed as very effective in marketing and information sharing (perhaps marketing is viewed as the main mandate by members);

- If a policy development/lobbying role is to be developed, a different approach may be required, including greater resources (perhaps from federal and provincial financial support), and greater formality (constitution, voting by members, elected officials and Provincial \& Federal economic development representatives on the Board);

- Development of a policy or position paper;

- The greater the number of members, the better the position of the Commission to influence policy; OEEDC should therefore strive for increased membership, drawing from as many communities as possible;

- The annual conference is an important tool to impact and influence policy development, and should continue to serve as an opportunity for input from members and an opportunity for information sharing;

- OEEDC is used as a model elsewhere in the Province;

- Impact at the local level is likely greatest at the rural and small urban area level, versus the larger urban areas;

- Inclusion of a high profile private sector representative on the Board.

\section{MPP survey results}

The survey was sent to the sixteen Eastern Ontario Members of Provincial Parliament. A total of four responses were received (25 per cent), of which:

- One MPP replied that responses are not given on opinion polls of Ontario organizations;

- Another MPP had not heard of OEEDC, but thought it might be a valuable body, and would welcome further discussion, given his/her interest in Eastern Ontario economic development;

- A third MPP stated a preference for learning more about the organization before participating in the survey;

- Finally, a fourth MPP thought that while OEEDC was relatively effective in influencing economic development related policies and programs in Eastern Ontario, a greater involvement of governments at all levels was recommended.

Informally, some MPPs contacted local economic development officers about the survey, basically expressing concern about participating in a survey on an organization that they did not know well (or at all). 
Survey results: Chamber of commerce, county wardens, mayors, CAOS, business development centres, CFDCS, BIAS

A survey was also sent to known Chambers of Commerce, County Wardens, Mayors, Municipal Chief Administrative Officers, Business Development Centres, Community Futures Development Corporations and Business Improvement Areas in Eastern Ontario (except Ottawa), and the Eastern Ontario Smart Growth Panel. As might be expected, the response rate was low, with a total of nine responses received.

In answer to the question, "How would you rate the effectiveness of the Commission to impact or influence economic development related policies and programs in Eastern Ontario", the following results were obtained.

Extremely effective -

Effective

Somewhat effective $34 \%$

Somewhat ineffective $10 \%$

Ineffective

Don't know

$56 \%$

In answer to the question, "What are your suggestions to increase the effectiveness of the Commission's influence on economic development related policies and programs", the following observations were provided by nine respondents.

- A number of respondents indicated they had no suggestions;

- One respondent suggested that the Board needs to set a strategy regarding this role. I feel that this is a new area in the political sphere. I am not against moving in this direction, however, before we do, we need to create a set of goals, objectives and strategies. At the present time, OEEDC is primarily a marketing organization, as well as, a facilitator of various other economic development functions;

- Some respondents proposed developing and implementing a communications strategy or plan;

- Another respondent suggested that the municipal councils should be one of the main target groups of a communications strategy;

- Still another respondent suggested the need to identify some issues critical to Eastern Ontario (i.e. Smart Growth), develop position papers, propose solutions and circulate that information to all municipal councils;

- Finally, a respondent commented that it is the feeling at the County level that OEEDC needs to enhance its profile and credibility, especially among non-EDOs. "What is it? Why does it exist? What are its objectives? What does it do? What is its relationship with the Province and the Ministry? What are the issues?" were questions raised. 


\section{OEEDC barriers to effective policy influence}

The research in this study has revealed that there are several barriers to increasing the effectiveness of the OEEDC's influence on policy.

1. The OEEDC does not have a clear mandate from its membership to be able to influence public policies.

2. The OEEDC is not well prepared to continuously scan the environment and to receive early warnings of upcoming economic issues that might be of concern to Eastern Ontario.

3. The OEEDC is limited in its ability to respond quickly when issues do arise, and relies on the availability and commitment of volunteers when it does respond.

4. The OEEDC does not currently have the capability of preparing well-researched and welldocumented positions on issues of concern.

5. The OEEDC needs partner organizations with which to "pursue the same policy agenda".

The first barrier exists due to a lack of a documented corporate mandate, mission, and vision. The second barrier exists because of limited connections with economic policy makers and implementers. The third and fourth barriers are related to the resource constraints of the Commission. The fifth barrier is attributed to a paucity of other active organizations with an Eastern Ontario focus.

\section{OEEDC opportunities}

One might easily speculate that Eastern Ontario is often the forgotten cousin within Ontario simply because it has not had any "squeaky wheels" to represent it in a proactive manner. Currently there is no leadership capable of assertively (or otherwise) representing the economic interests of Eastern Ontario.

- The Eastern Ontario Chambers of Commerce has been inactive for about four or five years. It was originally formed because of a perceived lack of focus on Eastern Ontario economic concerns;

- There is no Association of Municipalities of Ontario branch for Eastern Ontario similar to the Rural Ontario Municipal Association or the Northwestern Ontario Municipal Association;

- The Eastern Ontario County Wardens is an informal body, and excludes Eastern Ontario's largest city, Ottawa; 
- The Ontario Association of Community Futures Development Corporations is not involved in advocacy, but does have an Eastern Ontario presence;

- The Eastern Ontario MPP caucus no longer meets as a caucus to discuss Eastern Ontario issues;

- The Eastern Ontario Smart Growth Panel will soon be winding down;

- The Ontario East Tourism Corporation appears to be the other most active organization focusing specifically on Eastern Ontario.

The Eastern Ontario Smart Growth Panel recognized this economic development leadership vacuum in its very recently released discussion paper. The following represent recommendations specific to economic development:

- "That the Province recognise Eastern Ontario as an economic unit through an umbrella organization to improve branding and marketing of the region ... Such an organization could provide a broader range of services designed to meet the specific needs of the zone";

- "That the new umbrella economic development organization undertake as one of its first priorities, the development of an economic development strategy for the entire zone";

- "That the Province work with the new umbrella economic development organization to assist in the development and promotion of regional enterprise clusters which build on the zone's existing competitive advantages, in fields such as communications technology, life sciences (ie. Biotechnology), agriculture and photonics. Such an initiative should also include an awareness campaign to educate and attract additional participation from the broader community";

- "That the Province work with the new umbrella economic development organization to create, as an early priority task, an economic profile for all communities, market sectors and economic components of Eastern Ontario".

While the Smart Growth Panel recommendations do not go so far as to recommend that OEEDC be this new umbrella economic development organization for Eastern Ontario, the discussion paper does suggest "this could include the expansion and linking of mandates of organizations such as the Ontario East Economic Development Commission and the Ottawa Centre for Research and Innovation".

There is no alternative organization capable of facilitating the establishment of Eastern Ontario's economic priorities and communicating these priorities to senior governments. Nor is there any other organization capable of lobbying the government for action to address these economic priorities on behalf of Eastern Ontario. The OEEDC is indeed at the 'crossroads' of its own future, and the opportunity for OEEDC is to fill the economic leadership vacuum that exists in Eastern Ontario. The OEEDC can use its strength of membership to: 
- Establish economic priorities for Eastern Ontario;

- Actively pursue the establishment of senior government economic policies, programs, and financial allocations that are of economic benefit to Eastern Ontario;

- Act as a catalyst by working with and through other organizations with common economic interests in Eastern Ontario;

- Encourage and support the formation and development of other organizations with Eastern Ontario economic interests;

- Pursue the opportunities outlined by the Smart Growth Panel to contract with the Ontario Government, and possibly FedNor (Industry Canada) on a fee-for-service basis for the provision of a range of regional economic development services to be delivered in Eastern Ontario.

\section{Recommendations}

Organizational matters

The OEEDC has had at least two facilitated sessions in recent years. The last one, in December 2002, examined what form economic success would take in Eastern Ontario, and the barriers in existence preventing the realization of such success. Several years ago, a facilitated session was held that focused primarily on internal organizational matters. Despite the recommendations from the session, the OEEDC still lacks some key corporate documentation such as a mandate and/or mission statement, an organizational vision, and a long-range organizational development plan. The result is a lack of organizational clarity and direction, both for the membership and Board. A great strength of OEEDC is its broad membership base. The base should therefore be expanded to include all Eastern Ontario municipalities, so as to strengthen the OEEDC's ability to influence policy.

\section{Related recommendations}

- OEEDC should formalize organizational matters leading to the establishment of a clear mandate. For instance, consideration should be given to whether its current three roles of marketing, information sharing/communication, and advocacy of equal importance. The Northwestern Ontario Development Network provides a good example of a similar organization that has clearly documented its vision, members' needs, mandate, and mission statement (see www.nodn.com). 


\section{Board structure}

The current OEEDC Board structure consists of the President, Vice-President, Past President plus four other Board members. There is no federal or provincial representation on the Board, and one seat is currently filled with a private sector Board member.

Several other economic development organizations, especially regional organizations, benefit from the participation of senior government economic development staff, whether or not these staff are ex-officio, or have full voting privileges. All of the organizations with senior government participation on the Board expressed satisfaction with what is felt to be a mutually beneficial arrangement. These organizations felt that they benefited greatly from a close working relationship with senior government staff that frequently are in a position to supply information about impending changes that could be of interest, thereby providing an informal channel by which to influence policy development at its earliest stages.

Regional organizations further benefit from the participation of high profile private sector representatives on the Board. It was felt that these representatives lend credibility and profile to the Board and its organization (and sometimes political connections), thereby strengthening the degree of influence on the different levels of government.

\section{Related recommendations}

- The OEECD should add a few Board seats reserved for private sector representatives, and these positions should be filled in a manner that reflects the broad geographic and economic composition of Eastern Ontario.

- The OEEDC should add Provincial and Federal economic development representatives to the Board, with either full or observer status. Consideration should be given to the fact that organizational mandates for economic development within Ministries do change from time to time, so some flexibility should be maintained.

\section{Policy mandate}

A legitimate mandate designed to influence policy and address other OEEDC roles needs to be approved by the Board and its membership. The mandate should recognise and differentiate between policy development and influence specific to the Federal, Provincial and Local governments. There are a number of options available to the OEEDC in terms of its role;

1. No role in influencing policy;

2. Responsive role: react and respond as requested (current situation); 
3. Development of policy positions and represent them according to limitations imposed by availability of resources;

4. Set economic priorities, develop policy positions on the particular priorities, and seek their approval and implementation, thus taking a strong leadership position. This option demands more resources.

\section{Related recommendations}

- The Board should bring forward a mandate for membership approval that recognises and differentiates between policy development and influence, specific to the Federal, Provincial and Local governments.

- The OEEDC Board should seek approval for the above option 4, which would serve to increase the impact and influence on policy by the OEEDC on behalf of its membership. The approval of option 4 would represent a departure from the current culture of the organization and require additional resourcing.

- That the OEEDC should establish a policy committee responsible for:
a. Continuously searching for economic opportunities that could benefit Eastern Ontario. The committee should be assisted by Board members and OEEDC membership;
b. Responding quickly on as-required basis;
c. Directing the research and documentation for establishing OEED policy positions.
d. Seeking the necessary approvals for the policy positions.

- The Policy committee should determine matters of greatest economic development importance for Eastern Ontario that call for a policy position. Policy positions should be limited in number, particularly those directed at the Federal government.

- The OEEDC should determine the most cost-effective and efficient method of conducting policy research and development. For instance, in-house staff, a local University, consultants, or some combination thereof.

\section{Policy influence}

It should be noted that the ability to effectively influence and impact on policy does not necessarily equate to lobbying. In fact, the process of influencing policy for the purpose of this paper is seen as:

- Becoming informed about the economic issues and priorities of both government and Eastern Ontario, which involves ongoing communication and relationships with the concerned levels of government and communities;

- Developing well researched and documented positions on relevant issues and priorities; 
- Communicating these positions clearly to government bureaucrats and politicians that are in a position to respond to the issues and priorities.

The extent to which the organization becomes insistent and persistent in the pursuit of change or response should be determined by the membership which will likely vary according to the particular issue.

Having established a policy mandate and policy committee, representation of policy issues should become the next order of business for the OEEDC.

\section{Related recommendations}

The OEEDC should continue to utilize and expand the use of the annual conference to seek input, and to confirm Eastern Ontario priorities (particularly economic development priorities). This will serve not only to validate the positions to be advocated by OEEDC, but also the importance of municipalities being represented at the conference.

- The OEEDC should strive to make a presentation at least once within the term of each municipal Council, particularly after elections, to promote the benefits of membership in OEEDC, to seek input and confirmation of Eastern Ontario economic development priorities, and to obtain consultation on how the Commission can best serve municipalities (particularly small rural communities).

- The OEEDC Board should request an annual meeting with the MPPs of Eastern Ontario for the purpose of sharing information.

- The OEEDC Board should request meetings on an as-required basis with senior bureaucrats and individual Ministers (Federal and Provincial) to present positions of the OEEDC on issues of economic importance to Eastern Ontario.

- In addition to having Provincial and Federal Government economic development staff on the Board, they should be encouraged to actively participate at all meetings organized by the OEEDC. This should include scheduled presentations by Ministry staff on current and upcoming policy initiatives.

- The OEEDC should work with and through other organizations to the extent possible to advance the economic development agenda of Eastern Ontario.

\section{Resource issues}

The recommended mandate designed to influence policy cannot easily be achieved with the current resources available to the OEEDC. While annual membership fees are quite low, raising the membership fees alone will still not generate sufficient revenues. Other funding options must be considered, and there are precedents of senior governments providing substantial 
funding support to other regional economic development organizations as noted in this report. Further research in this area should be undertaken.

\section{Related recommendations}

- The OEEDC should approach senior government Ministries to explore the possibility of providing fee-for-service based economic development services for Eastern Ontario. Some possibilities include:

a. Marketing services for all of Eastern Ontario (in addition to cooperative marketing);

b. The provision of a forum for the announcements of Provincial policies, programs and projects;

c. The provision of project sponsorship for the development of sub-regional economic strategies in rural Eastern Ontario, utilizing OSTAR funding;

d. The provision of economic development education for new Councils.

- The OEEDC should investigate other revenue generating possibilities that may exist, such as sponsoring more frequent or more comprehensive professional development and education seminars, the provision of economic development services on behalf of those municipalities without professional economic development staff, or possibly applying for PEMD-I project funding.

- The OEEDC should review its membership fee structure in light of the increased value that will be provided by OEEDC as a result of changes recommended in this paper.

\section{Next Steps}

The OEEDC Board and members have explored the possibilities of a larger and more active mandate for the organization. The Board must take the next steps to initiate discussions with its membership on the desirability of pursuing an enhanced role and mandate for the OEEDC as proposed in this paper.

\section{Related recommendations}

- This paper should be presented at the next Ontario East Municipal Conference to serve as a basis for stimulating discussion.

- The Board should prepare the necessary changes recommended in this paper for discussion and amendment or approval at this year's Ontario East Municipal Conference.

- In the interim, the Board should explore funding resource options that may be available, and report the outcome at the Ontario East Municipal Conference. 


\section{Author's Biography}

Eric McSweeney is an Economic Development and Local Government Management Consultant providing practical guidance and assistance based upon 24 years of Canadian Local Government experience. Eric recently formed McSweeney \& Associates (www.mcsweeney.ca) to offer clients a unique combination of experiences in economic development, real estate, and municipal management. In addition to providing consultant resources in Canada, Eric has taken on assignments throughout Central and Eastern Europe, including Lithuania, Latvia, Estonia, Hungary, Poland, Slovakia, Romania, Serbia and Bosnia and Herzegovina. His publications include the Handbook for Analysing and Documenting the Urban Economic Base published by the Fiscal Decentralization Initiative for Central and Eastern Europe. His training materials have been translated into nine languages.

Eric completed his undergraduate degree at Carleton University, is a certified Economic Developer, maintains two real estate certifications, and is also a Business Retention and Expansion International certified consultant. He is currently a member of the Board of Directors and the Executive Committee of the Greater Ottawa Chamber of Commerce.

\section{References}

Blais, Paul and Chris King. (2003). Blueprint for Prosperity in Ontario East: A Position Paper for the Ontario East Economic Development Commission.

Eastern Ontario County Wardens. (2002). Future Directions: Presentation to the Honourable Chris Hodgson, Minister of Municipal Affairs and Housing.

Ontario East Economic Development Commission. (2003). Constitution and By-laws.

Ontario East Economic Development Commission. (2003). $15^{\text {th }}$ Anniversary: History in the Making, 1988-2003.

Ontario East Economic Development Commission. (2003). www.onteast.com.

Queen's University Executive Decision Centre. (1997). Planning Workshop, Ontario East Economic Development Commission.

Queen's University Executive Decision Centre. (2002). Ontario East Economic Development Commission, Brainstorming Session Highlights, December.

The Ontario Rural Council. (2003). Rural Campaign Action! Bulletin. 